\title{
Effect of Coconut Fibre on the Mechanical and Corrosion Properties of Reinforced Concrete in Marine Environment
}

\section{Farooq A*, Saleem A and Ahmad R}

Corrosion Control Research Cell, Department of Metallurgy and Materials Engineering, College of Engineering and Emerging Technologies, University of the Punjab, Lahore-54590, Pakistan

\begin{abstract}
The aim of the research was to enhance the mechanical and corrosion properties by adding coconut fibre in the concrete. Different compositions of concrete mixtures using Ravi and Chenab sand with and without fibre have been prepared. The mechanical properties were evaluated by compression and pull-out strength while corrosion properties by measuring half-cell potential before and after exposing to the different time duration in marine environment. As the different concrete possesses the complex properties, thus by the addition of fibres, improvement in all properties is not observed. The improved swell and crack resistance was also notified. However, adverse effects were observed in the compressive strength after introduction of fibres. Cumulatively, better corrosion resistance, $20 \%$ lesser compressive strength, $17 \%$ higher pull-out strength and higher moisture absorption was observed for fibre reinforced concrete as compared with plain concrete.
\end{abstract}

Keywords: Coconut fibre; Concrete; Pull-out strength; Compression strength; Corrosion resistance

\section{Introduction}

Concrete is used as a safe, durable and basic building material everywhere in the world. According to a rough estimate world consumes 10 billion tons of concrete every year. It is known that Portland cement concrete is a brittle material. Tensile strength of concrete is very low, narrow ductile range and low crack resistance. Micro cracks exist in the concrete and because of its lesser tensile strength, propagation of micro cracks occurs, leading concrete towards brittle behavior. In concrete and other materials having brittle nature, drying shrinkage and other causes generates the cracks before loading. These internal micro cracks propagate on the application of load and cause additional cracking [1]. Corrosion of steel reinforcement is the one of the main and expensive deterioration mechanisms affecting the reinforced concrete structures. As in highly alkaline environment, protective oxide film is formed, it is unlikely that good quality concrete reinforced steel corrode even if a sufficient moisture and oxygen is present there [2]. However, ingress of carbon dioxide initiates carbonation or drops the alkalinity of the environment [3]. This reduction in alkalinity of environment and presence of aggressive ions in high concentrations (primarily chlorides) disturbs the passive layer of the reinforced steel thus corrosion begins [4]. Addition of fibres results in reduction of micro cracks but over a period of long time steel corrodes because of corrosion action. Service life of reinforced concrete structure, in terms of corrosion, can be predicted with respect to these periods of time: initiation period (the departure time of external corrosion agent into the concrete and depassivation of steel bars) and propagation period (the period in which active corrosion occurs and product of this process gather, cause the cracking and spalling of the concrete structure [5]. The depth of concrete cover and its quality are the most important factor affecting the corrosion process in reinforcement, as the concrete cover acts as a barrier for corrosive elements [6]. However cracks originated from other sources like shrinkage, thermal gradients and/or mechanical loading are also present in reinforced concrete structures. Usually these cracks are the paths for the external agents [7]. The toughness and tensile properties of Concrete containing fibres is much better than the conventional simple concrete. Also the fibres arrests the corrosion process (and crack propagation) of the concrete, by allowing narrowed path to the external agents, even for less than $1 \%$ fibre content [8]. Gjorv specified an investigation of Norway OPC extensions showing that $1 / 4^{\text {th }}$ of those constructed after 1970, faced corrosion issues [9]. Ferreira investigated the 600.000 bridges in the USA according to their research corrosion affected $40 \%$ bridges and a cost of 50 billion dollars is required for repairing. At the other end, reinforced steel is a material of high cost, used for high energy consumption and manufactured from non-renewable sources. There is a need to put light on the usage of organic or inorganic fibers in concrete which is economic as well as ecofriendly [10]. Numerous studies have been taken on the benefits of adding fibres with respect to corrosion. As the fibres arrest the further cracking produced by corrosion products and also hinders the path of external corrosive agents. Thus, reported results show that added fibres have a positive effect on the corrosion rate [11]. In one study Sappakittipakorn and Banthia [12] while in another study Blunt et al. [13] reported the same results. Ali et al. [14] worked to find the effect of coconut fibres reinforcement on the mechanical and dynamic properties of the concrete in a very comprehensive way. They investigated the comparison between moduli in dynamic and static conditions while, using the different fibre contents $(1 \%, 2 \%, 3 \%$ and $5 \%)$ of different lengths $(2.5,5$ and $7.5 \mathrm{~cm})$. The effect of fibres in increasing the compressive strength is very little. According to a rough estimation increment in compressive strength of concrete by the addition of fibres can be nil or up to $25 \%$. Even for the conventional concrete with reinforcement or concrete containing steel fibre the effect of fibre addition on compressive strength is very little. Though, the effect of fibre on the post cracking ductility or energy absorption is notable [1].

*Corresponding author: Farooq A, Research Officer, Corrosion Control Research Cell, Department of Metallurgy and Materials Engineering, College of Engineering and Emerging Technologies, University of the Punjab, Lahore-54590, Pakistan, Tel: +92-42-35832604; E-mail: ameeq.farooq@gmail.com

Received August 24, 2017; Accepted August 31, 2017; Published September 06, 2017

Citation: Farooq A, Saleem A, Ahmad R (2017) Effect of Coconut Fibre on the Mechanical and Corrosion Properties of Reinforced Concrete in Marine Environment. J Steel Struct Constr 3: 132. doi: 10.4172/2472-0437.1000132

Copyright: ( 2017 Farooq A, et al. This is an open-access article distributed under the terms of the Creative Commons Attribution License, which permits unrestricted use, distribution, and reproduction in any medium, provided the original author and source are credited. 
This project is presenting some results from an ongoing project aimed at determining the effects of coconut fibre reinforcement on mechanical properties (compressional strength and tensile strength) of concrete as well as the on the corrosion process of re-bars embedded in concrete. In specific, the corrosion and mechanical properties of concrete specimens, exposed for different time in marine are assessed and compared by material testing of both plain concrete specimens and fibre containing concrete specimens.

\section{Experimental Work}

The composition of used concrete is given in Table 1.

Two different sands Ravi and Chenab sand were used in this research work. Ravi sand of the mesh no. 70, Chenab sand of the mesh no. 40 and aggregate of the mesh no.6 were used. Corrosion behavior of each concrete type was study by monitoring the reduction potential variation with respect to the time. ASTM C39 was followed for the compressional testing and to study the effect of fibre addition on the compression strength. To test the effect of fibre addition on the pull out strength of concrete ASTM C900 was used. Tensile machine with a loading capacity of $10,000 \mathrm{kN}$ was used for pull-out testing.

\section{Results and Discussion}

\section{Chemical analysis of concrete constituents}

Chemical analysis of each constituent of concrete is performed to find their compositions. Chenab and Ravi both types of sand consist on lime $(\mathrm{CaO})$, insoluble incombustible or nonvolatile materials and combustible materials. Although, Chenab sand contains large amount of the insoluble materials as compared with the Ravi sand. Ravi sand contains finer particles as compared with the Chenab sand particles.

Similarly for cement the main constituents are lime $(\mathrm{CaO})$, silica, nonvolatile insoluble materials and volatile materials. The chemical analysis of each is given below in Table 2 .

\begin{tabular}{|c|c|c|}
\hline Constituents & Percentage \% & Percentage \% \\
\hline Cement & 29 & 29 \\
\hline Aggregate & 24 & 24.5 \\
\hline Sand & 32 & 32 \\
\hline Water & 14.5 & 14.5 \\
\hline Fiber & 0.5 & - \\
\hline
\end{tabular}

Table 1: Percentage composition (by weight) of ingredients.

\begin{tabular}{|c|c|}
\hline (A) Constituents & Percentage \\
\hline Lime (CaO) (wt. \%) & 3.07 \\
\hline Insoluble Material (in HCl) (wt. \%) & 95.77 \\
\hline Loss on Ignition (wt. \%) & 0.13 \\
\hline (B) Constituents & Percentage \\
\hline Lime (CaO) (wt. \%) & 2.4 \\
\hline Insoluble Material (in HCl) (wt. \%) & 93.83 \\
\hline Loss on Ignition (wt. \%) & 0.18 \\
\hline & \\
\hline (C) Constituents & Percentage \\
\hline Lime (wt. \%) & 65.15 \\
\hline Silica (wt. \%) & 21.53 \\
\hline Loss on Ignition (wt. \%) & 1.73 \\
\hline Insoluble Residue (wt. \%) & 2.15 \\
\hline
\end{tabular}

Table 2: Chemical analysis of concrete constituents: (A) Chemical composition of Chenab sand; (B) Chemical composition of Ravi sand; (C) Chemical composition of cement.

\section{Moisture absorption}

The moisture absorption of each specimen placed in sea water was noted. Weights of these specimens were noted before placement in the sea water and after removal. On the basis of differential weights their percentage absorptions were calculated by utilizing eqn. (1).

$$
\% w_{a}=\left(\frac{W_{f}-W_{i}}{W_{i}}\right) \times 100
$$

Where, $\mathrm{w}_{\mathrm{a}}=$ percentage absorption, $\mathrm{w}_{\mathrm{f}}=$ weight after removal, $\mathrm{w}_{\mathrm{i}}=$ initial weight (Table 3 ).

The percentage moisture absorptions of RS and RSF concrete are compared in Figure 1.

The moisture absorption of RSF was $31.21 \%, 21.39 \%, 19.63 \%$ and $13.44 \%$ higher than the moisture absorption of RS concrete specimens after the exposure of 792 hours, 1656 hours, 3216 hours and 4128 hours, respectively. But After 2280 hours the moisture absorption of RS was observed 9.16\% higher than RSF concrete specimens.

Whereas, the percentage moisture absorption of CS and CSF concrete specimens are compared in Figure 2. CSF concrete specimens absorbed $7.50 \%, 44.90 \%, 0.93 \%$, and $20.88 \%$ higher moisture than the CS concrete specimens after the exposure of 792 hours, 1656 hours, 3216 hours and 4128 hours respectively. But after 2280 hours the moisture absorption of CS was observed $1.20 \%$ higher than CSF concrete specimens. The moisture absorption of the CS concrete specimens was $22.26 \%, 67.87 \%, 4.38 \%$ and $14.45 \%$ higher than the moisture absorption of RS concrete specimens, for the exposure of 792 hours, 1656 hours, 3216 hours and 4128 hours respectively. The moisture absorption of RS concrete specimen was $30.3 \%$ higher than the moisture absorption of CS for 2280 hours. Obviously the moisture absorption of fibre based concrete should be higher than the simple

\begin{tabular}{|c|c|c|c|c|}
\hline \multirow{2}{*}{ Time (hours) } & \multicolumn{4}{|c|}{ Water absorption (\%) } \\
\cline { 2 - 5 } & RS & RSF & CS & CSF \\
\hline 792 & 4.11 & 5.98 & 5.3 & 5.73 \\
\hline 1656 & 1.69 & 2.15 & 5.26 & 9.54 \\
\hline 2280 & 7.62 & 6.98 & 5.86 & 5.78 \\
\hline 3216 & 6.09 & 7.59 & 6.37 & 6.44 \\
\hline 4128 & 5.09 & 5.88 & 5.95 & 7.52 \\
\hline
\end{tabular}

Table 3: Percentage moisture absorption with different exposure time.

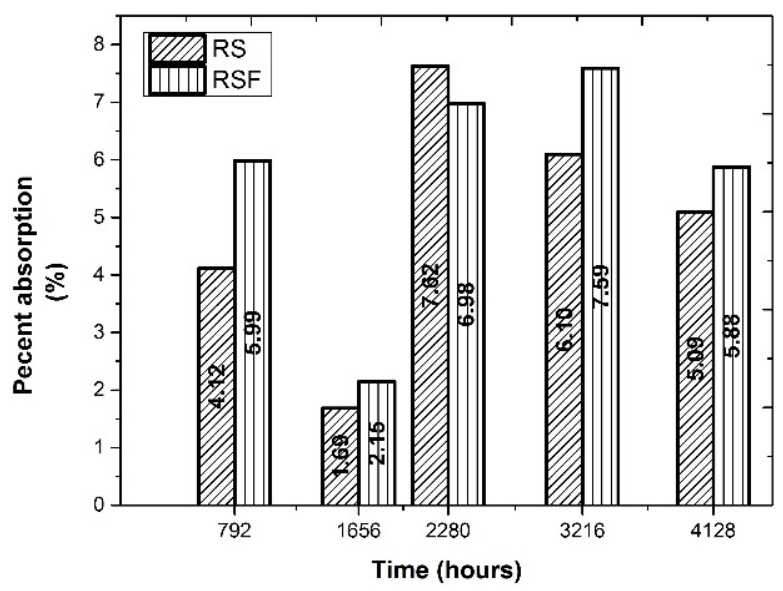

Figure 1: Moisture absorption of RS and RSF concrete with different exposure time. 
concrete. Similar behavior can be observed by the Figures 1 and 2 the moisture absorption of fibre based specimens are higher as compared with specimens of simple concrete.

\section{Half-cell potential readings}

The corrosion study was done by noting the reduction potential through the corresponding standard electrodes. For sea water saturated calomel electrode (SCE) was used and the relative potential readings (taken at different exposure time) of each concrete type is provided in Table 4. Higher reduction potential of a material indicates that the material is at noble side, which means safer from corrosion.

Figure 3 is the comparison between the potential variations of RS and RSF concrete under the influence of sea water. The values are provided in Table 4.

It is illustrated in Figure 3 that at the initial stages when the specimens were introduced to the moisture, RS specimen possessed the higher potential which means more protection from the corrosion process as compared with RSF concrete. But then the potential of RSF concrete increased and a shift towards noble side can be observed. After the exposure of 2328 hours the RSF potential started to become less favorable for corrosion process. The reason behind this behavior is higher moisture absorption rate of fibre reinforced concrete, which absorbed more moisture than the simple concrete (RS) absorbed lesser moisture at the initial stages. But after absorbing sufficient moisture

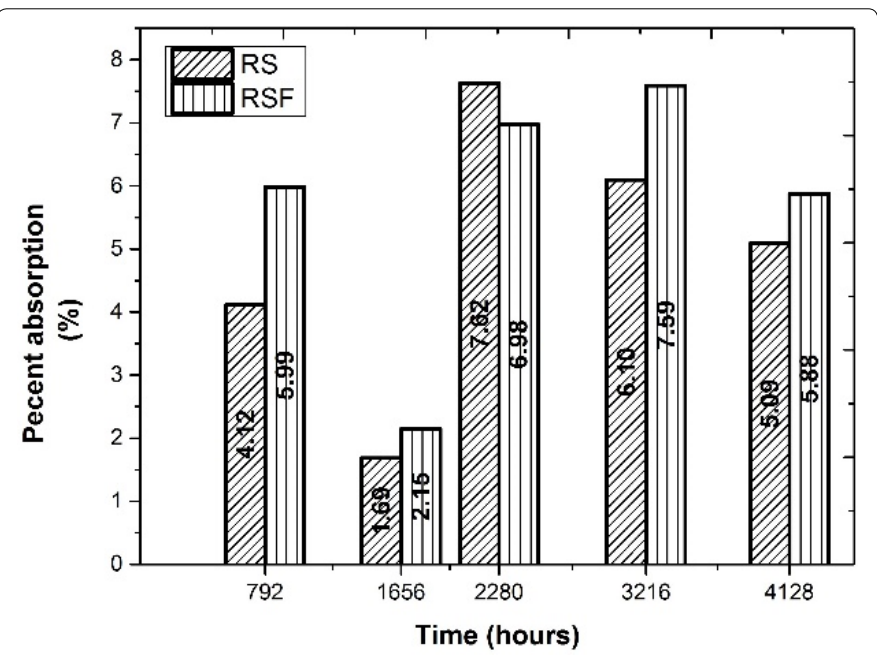

Figure 2: Moisture absorption of CS and CSF concrete with different exposure time.

\begin{tabular}{|c|c|c|c|c|}
\hline \multicolumn{5}{|c|}{ Half-cell potential $(\mathbf{m V})$ vs. SCE } \\
\hline $\begin{array}{c}\text { Time } \\
\text { (hours) }\end{array}$ & CS & CSF & RS & RSF \\
\hline 1632 & 370 & 393 & 532 & 411 \\
\hline 1848 & 343 & 329 & 366 & 367 \\
\hline 2112 & 349 & 343 & 372 & 350 \\
\hline 2328 & 332 & 318 & 343 & 343 \\
\hline 2520 & 277 & 258 & 268 & 281 \\
\hline 2784 & 274 & 262 & 251 & 276 \\
\hline 3144 & 306 & 303 & 314 & 338 \\
\hline 3240 & 296 & 287 & 299 & 314 \\
\hline 3408 & 274 & 262 & 251 & 276 \\
\hline 3504 & 201 & 282 & 295 & 290 \\
\hline 4080 & 309 & 292 & 260 & 288 \\
\hline
\end{tabular}

Table 4: Half-cell potential of concrete specimens placed in marine environment.

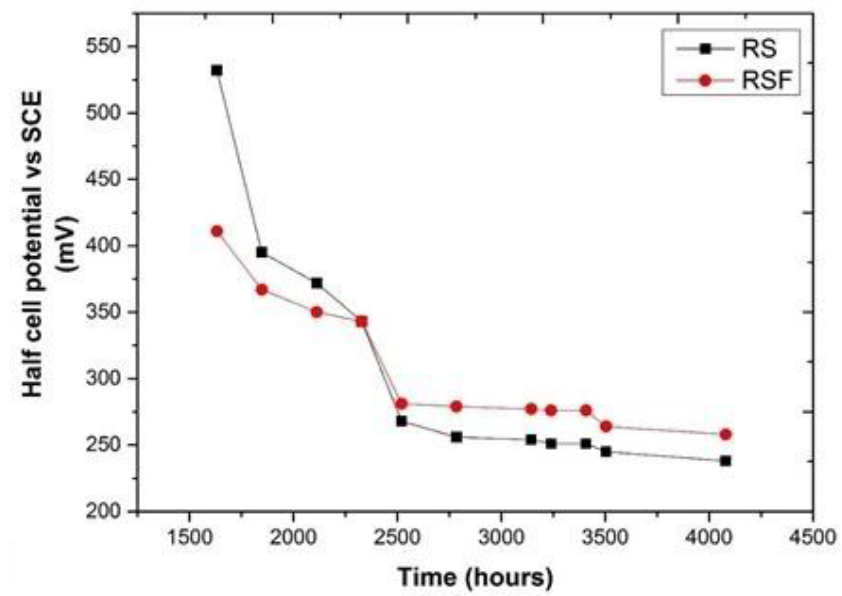

Figure 3: Comparison of Half-cell potential variation among RS and RSF specimens.

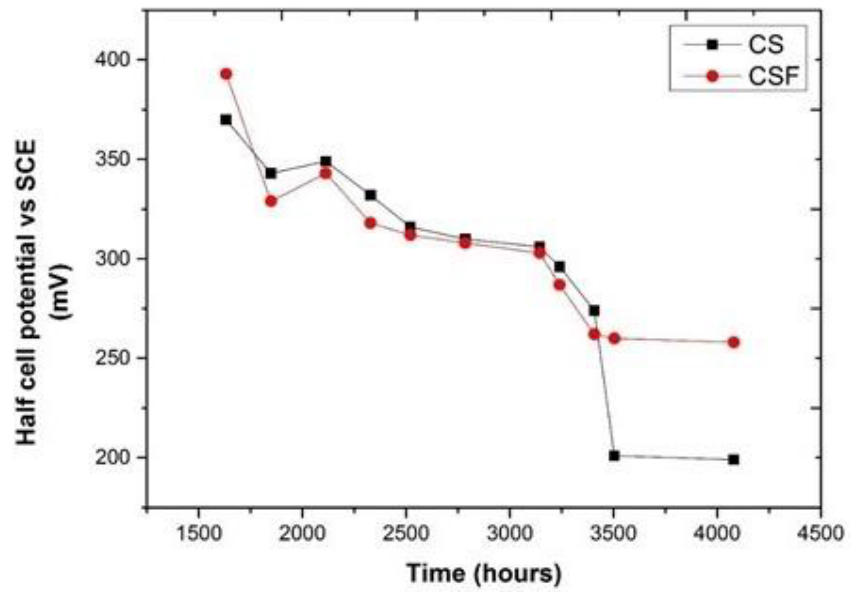

Figure 4: Comparison of Half-cell potential variation among CS and CSF specimens.

fibres present in RSF started to hinder the movement of aggressive ions thus before the 2328 hours of exposure, RSF potential was at active side then after this point became noble as compared with the RS potential.

The potential variation of CS and CSF concrete given in Table 4, are compared in Figure 4. At the beginning CSF concrete was less favorable for the corrosion than the CS concrete. Then potential of CS concrete became more positive (noble) than the potential of CSF. After the exposure of 3408 hours a shift in the potential of both concrete can be noticed. The CSF potential shifted towards noble side whereas the CS potential moved toward active side. Again the reason of this behavior is higher moisture absorption rate of fibre reinforced concrete than the simple concrete. But after absorbing a sufficient amount of moisture, fibres provided higher hindrance in the path of electrolyte than the simple concrete. As we know although, CS consisted of larger particles as compared with RS. But the penetration of moisture in CS concrete was observed very slow as compared with RS concrete (in the presence of lesser amount of moisture). Thus lesser moisture amount in the CS concrete protected the steel reinforced bar from corrosion. 


\section{Compression strength}

The detail of the compression strengths and fracture types of all concrete types exposed to the sea water are given in Tables 5-8.

Comparison between compression strengths of concrete specimens: Figure 5 is providing this comparison. According to which it is clear that till the exposure of 2280 hours the compression strength of RS concrete specimens is higher than the RSF concrete specimens. The compression strength of RS concrete observed 30.21\%, $49.07 \%$, $11.67 \%$ and $40.36 \%$ higher than the compression strength of RSF concrete specimens tested after exposures of 0 hour, 792 hours, 1656 hours and 2280 hours respectively. The compression strengths of RSF specimens were $10.11 \%$ and $19.87 \%$ higher than RS concrete specimens tested after exposures of 3216 and 4128 hours respectively. This whole trend is shown in Figure 5.

Peculiar behavior of the RS concrete for the last two periods, can

\begin{tabular}{|c|c|c|c|}
\hline \multirow{2}{*}{ No. } & Time (hours) & \multicolumn{2}{|c|}{ RS } \\
\cline { 3 - 4 } & & $\begin{array}{c}\text { Compression strength } \\
\text { (lb/in }^{2} \text { ) }\end{array}$ & Fracture Type \\
\hline 1 & 0 & 3534.66 & 3 \\
\hline 2 & 792 & 3467.54 & 3 \\
\hline 3 & 1656 & 3222.62 & 2 \\
\hline 4 & 2280 & 3623.2 & 3 \\
\hline 5 & 3216 & 2494.47 & 1 \\
\hline 6 & 4128 & 3222.62 & 2 \\
\hline
\end{tabular}

Table 5: Compression strength values for RS.

\begin{tabular}{|c|c|c|c|}
\hline \multirow{2}{*}{ No. } & Time (hours) & \multicolumn{2}{|c|}{ RSF } \\
\cline { 3 - 4 } & & $\begin{array}{c}\text { Compression } \\
\left.\text { strength (lb/in } \mathbf{2}^{2}\right)\end{array}$ & Fracture Type \\
\hline 1 & 0 & 2466.55 & 3 \\
\hline 2 & 792 & 1766.02 & 3 \\
\hline 3 & 1656 & 2846.49 & 5 \\
\hline 4 & 2280 & 2160.78 & 2 \\
\hline 5 & 3216 & 2746.76 & 1 \\
\hline 6 & 4128 & 3863.1 & 3 \\
\hline
\end{tabular}

\begin{tabular}{|c|c|c|c|}
\hline \multirow{2}{*}{ No. } & \multirow{2}{*}{ Time (hours) } & \multicolumn{2}{|c|}{ RSF } \\
\cline { 3 - 4 } & & $\begin{array}{c}\text { Compression } \\
\text { strength (lb/in') }\end{array}$ & Fracture Type \\
\hline 1 & 0 & 2791.77 & 2 \\
\hline 2 & 792 & 3906.343 & 6 \\
\hline 3 & 1656 & 3165.89 & 2 \\
\hline 4 & 2280 & 3741.36 & 1 \\
\hline 5 & 3216 & 3440.38 & 2 \\
\hline 6 & 4128 & 4260.31 & 3 \\
\hline
\end{tabular}

Table 7: Compression strength values for CS.

\begin{tabular}{|c|c|c|c|}
\hline \multirow{2}{*}{ No. } & Time (hours) & \multicolumn{2}{|c|}{ RSF } \\
\cline { 3 - 4 } & & $\begin{array}{c}\text { Compression } \\
\left.\text { strength (lb/in }{ }^{2}\right)\end{array}$ & Fracture Type \\
\hline 1 & 0 & 2476.24 & 3 \\
\hline 2 & 792 & 3005.7 & 2 \\
\hline 3 & 1656 & 2384.99 & 3 \\
\hline 4 & 2280 & 2915.27 & 1 \\
\hline 5 & 3216 & 3339.39 & 2 \\
\hline 6 & 4128 & 3228.25 & 3 \\
\hline
\end{tabular}

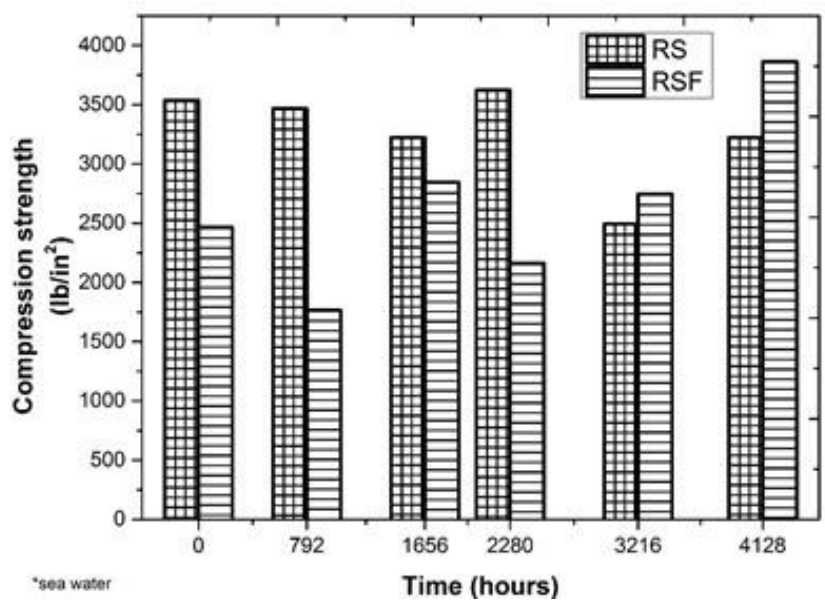

Figure 5: Comparison between the compression strengths of RS and RSF specimens.

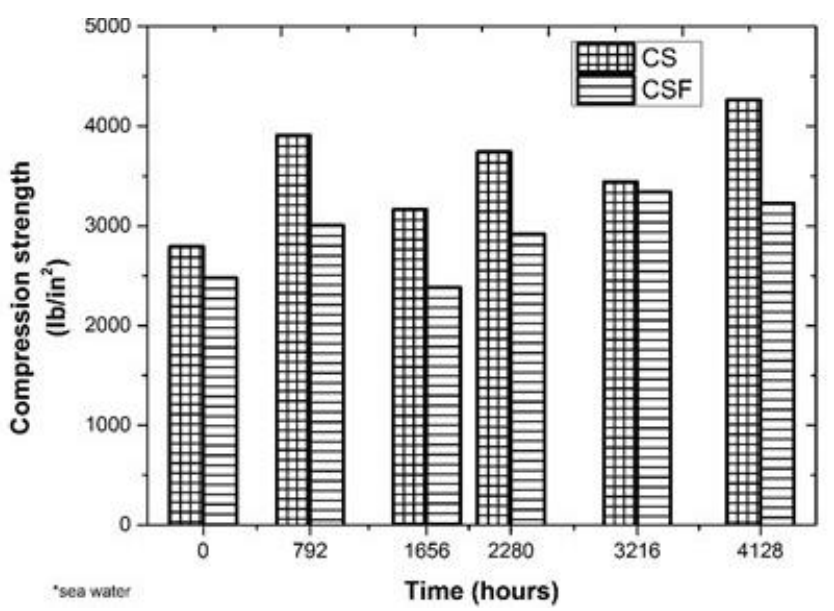

Figure 6: Comparison between the compression strengths of CS and CSF specimens.

be explained with the help of increased moisture content, increased exposure time, presence of voids, improper filling. The comparison of the compression strengths of both CS and CSF is shown in Figure 6.

In which it can be clearly seen that the compression strengths of CS concrete specimens are higher than the CSF concrete specimens throughout the graph. The compression strengths of RS concrete specimens are $11.30 \%, 23.06 \%, 24.66 \%, 22.08 \%, 2.93 \%$ and $24.22 \%$ higher than the RSF concrete specimens tested after exposures of 0 hour, 792 hours, 1656 hours, 2280 hours, 3216 hours and 4128 hours, respectively.

Effect of fibre reinforcement on the compressive failure: Figures 7 and 8 are describing the concrete behavior after the compressive failure. Although the compression strength obtained with the fibre reinforced concrete (RSF and CSF) was lesser than the compressive strength of simple concrete (RS and CS) but the post cracking behavior of fibre reinforced concrete was much beneficial.

Post cracking ductility was seen in the compressive failure of fibre reinforced concrete. Which means after generation and propagation of cracks throughout the specimen, failure occurred but fragments stayed at their place. Whereas brittle behavior was observed in the compressive 


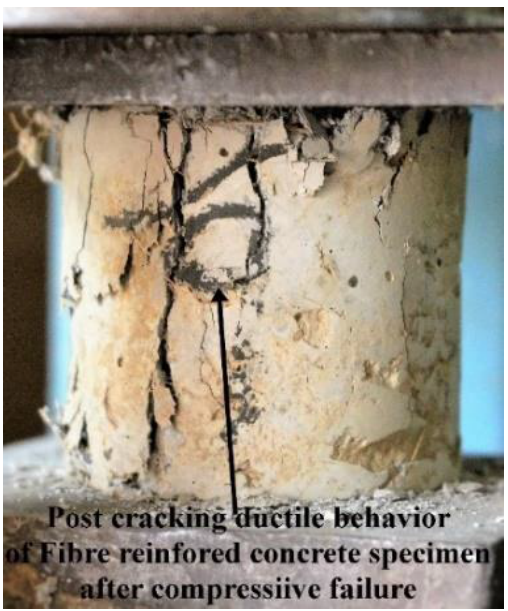

Figure 7: Fibre reinforced concrete after compressive failure.

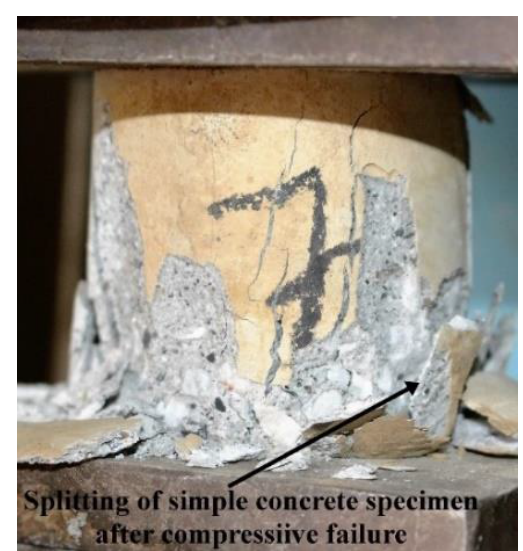

Figure 8: Simple concrete after compressive failure.

failure of simple concrete, in which the fragments of concrete left their places after the compressive failure.

\section{Pullout testing}

Pull-out test was utilized to monitor the effects of fibre addition and surrounding environment on the bond between concrete and steel reinforcement. The pull-out strengths (loads) of the specimens placed in sea water are given in the Table 9 after different exposure time durations. Figures 9 and 10 are the comparison of pull-out strengths between concrete specimens.

It is clear that the pull-out strengths of fibre based concrete specimens are higher than that of simple concrete specimens. The pullout strength of RSF concrete observed $33.33 \%, 62.5 \%$ and $4 \%$ higher than the RS concrete after the exposure of 2328 hours, 3288 hours and 3576 hours. The pull-out strength of RS was $10.71 \%$ higher than RSF pull-out strength. The large amount of contraction cracks present on the RSF (tested after 4104 hours) caused reduction in the comparative pull-out strength.

The pull-out strength of fibre reinforced concrete CSF was observed $40 \%, 25 \%$ and $16.66 \%$ higher than the CS concrete for the exposure time of 2328 hours, 3576 hours and 4104 hours respectively. But for the exposure time of 3288 hours the pull-out strength of CSF was $30 \%$ lower than the CS. On an average again fibre reinforced concrete

\begin{tabular}{|c|c|c|c|c|}
\hline \multirow{2}{*}{ Time (hours) } & \multicolumn{4}{|c|}{ Water absorption (\%) } \\
\cline { 2 - 5 } & RS & RSF & CS & CSF \\
\hline 2328 & 9 & 12 & 15 & 16 \\
\hline 3288 & 13 & 12 & 10 & 19.5 \\
\hline 3576 & 10.5 & 12.5 & 14 & 13 \\
\hline 4104 & 10 & 15.5 & 12 & 14 \\
\hline 4128 & 5.09 & 5.88 & 5.95 & 7.52 \\
\hline
\end{tabular}

Table 9: Pull-out load of concrete specimens placed in sea water.

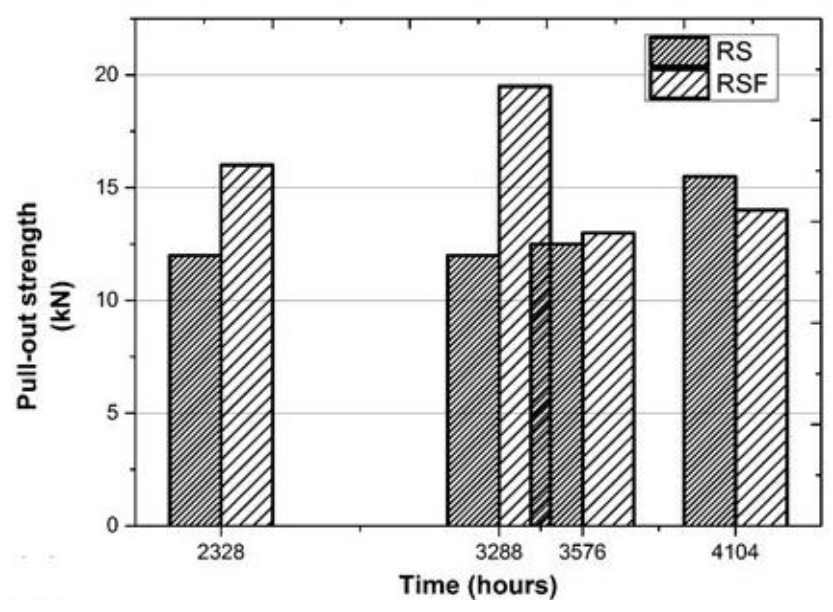

Figure 9: Pull-out strength of RS and RSF concrete specimen.

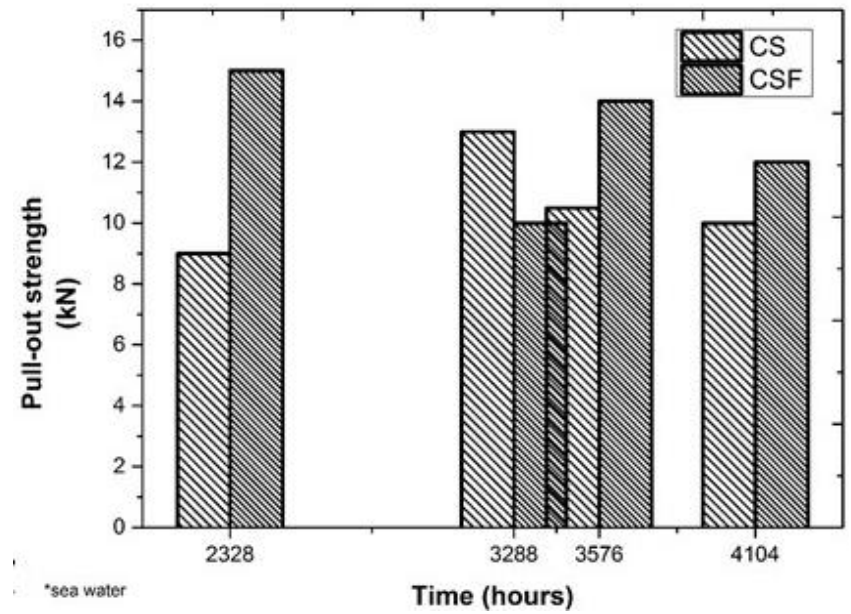

Figure 10: Pull-out strength of CS and CSF concrete specimens.

exhibit the higher pull-out strength. On an average the pull-out strength obtained by RS concrete was higher than the CS concrete. According to literature, the pullout and bond strength of concrete increases with the increasing amount of moisture and fibre reinforcement. This is proved true with this experiment. As all fibre containing specimens showed higher strength and absorption as compared with the plain concrete specimens.

Effect of fibre reinforcement on the pull-out failure: By the above discussion it is clear that by the addition of fibres, pull-out strength of concrete increased i.e., when reinforcement bar was embedded in the fibre based concrete it became relatively difficult to pull that reinforcement out as compared with when the reinforcement bar was 


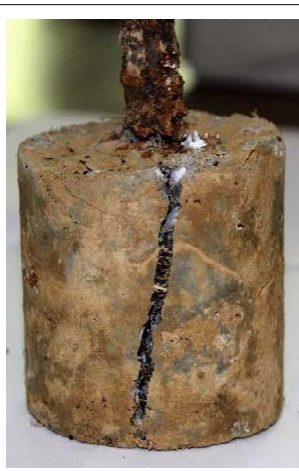

Figure 11: Pull-out failure behavior of the Fibre based concrete specimen

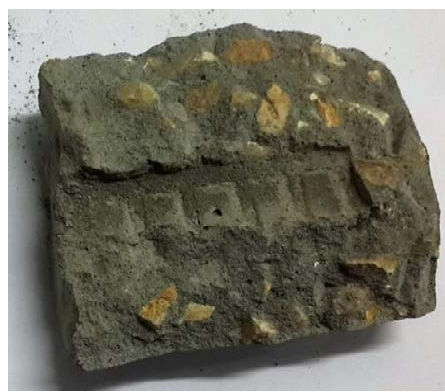

Figure 12: Pull-out failure of simple concrete specimen.

embedded in simple concrete. Another benefit of fibre addition is shown in Figure 11.

In which the fibre reinforced concrete core sustained its shape after pull-out failure, although cracks appeared. While the breakage occurred at the steel-concrete bond so the steel lost its grip result the pull-out failure. Different failure was observed with the simple concrete specimens as shown in Figure 12.

The concrete core split into the pieces after the failure and the steel-concrete bond also destroyed, leaving behind the marks of grooves present at the steel reinforced bar. In other word fibre based concrete followed the slip type failure mechanism and simple concrete specimens followed the split type failure mechanism.

\section{Conclusion}

The conclusion of the research work was as follows:

- Addition of fibre into concrete protects the steel reinforcement from corrosion in a better way as compared with the plain concrete

- Comparatively Higher pullout and bond strength was observed for the specimens based on fibre containing concrete

- Observed Compressive strength of plain concrete specimens was higher than that of fibre containing specimens

- Chenab sand based concrete Specimens possessed higher absorption as compared with the plain concrete specimens.

\section{References}

1. Vajje S, Krishna MNR (2013) Study on addition of the natural fibers into concrete. International Journal of Scientific and Technology Research 2: 213218.

2. Elsener B (2002) Macrocell corrosion of steel in concrete - implications for corrosion monitoring. Cement and Concrete Composites 24: 65-72.
3. Andrade C, Alonso C (2001) On-site measurements of corrosion rate of reinforcements. Construction and Building Materials 15: 141-145.

4. David T, Ceki H, Kenneth R (2009) Corrosion performance tests for reinforcing steel in concrete: Technical Report. Texas Department of Transportation Research and Technology Implementation Office P. O. Box 5080 Austin, Texas, Report No. FHWA/TX-09/0-4825-1.

5. Tuutti K (1982) Corrosion of Steel in Concrete. Swedish Cement and Concrete Research Institute, pp: 1-473.

6. Francois R, Maso $\mathrm{J}$ (1988) Effect of damage in reinforced concrete on carbonation or chloride penetration. Cement and Concrete Research 18: 961-970.

7. Wang K, Jansen DC, Shah SP, Karr AF (1997) Permeability study of cracked concrete. Cement and Concrete Research 27: 381-393.

8. Lárusson LH (2013) Development of Flexible Link Slabs using Ductile Fibe Reinforced Concrete. Ph.D. thesis, Department of Civil Engineering Technical University of Denmark.

9. Gjorv OE (1994) Steel corrosion in concrete structures exposed to Norwegian marine environment. ACI Concrete International 16: 35-39.

10. Ferreira RM (2000) Tests for Evaluation of Concrete Durability. Master Thesis, University of Minho.

11. Mihashi H, Faiz S, Ahmed U, Kobayakawa A (2011) Corrosion of reinforcing steel in fiber reinforced cementitious composites. Journal of Advance Concrete Technology 9: 159-167.

12. Sappakittipakorn M, Banthia N (2012) Corrosion of Rebar and Role of Fiber Reinforced Concrete. Journal of Testing and Evaluation 1: 127-136.

13. Blunt J, Jen G, Ostertag C (2015) Enhancing corrosion resistance of reinforced concrete structures with hybrid fiber reinforced concrete. Corrosion Science 92: 182-191.

14. Ali M, Liu A, Sou H, Chouw N (2013) Mechanical and Dynamic Properties of Coconut Fibre Reinforced Concrete. Construction and Building Materials, 5: 814-825. 